\title{
ANALISIS KESESUAIAN ANTARA LAPORAN KEUANGAN PEMERINTAH DESA DENGAN PEDOMAN PENGELOLAAN KEUANGAN DESA PERMENDAGRI NOMOR 113 TAHUN 2014 \\ (STUDI KASUS PADA LAPORAN KEUANGAN TA 2016 PEMERINTAH DESA REMPANGA)
}

\author{
Wijoseno Lelono \\ Titin Ruliana \\ Umi Kulsum
}

\author{
University of 17 Agustus 1945 Samarinda \\ Jl. Ir. H. Juanda No. 80, 75124, Indonesia \\ jeamlvpool@gmail.com
}

\begin{abstract}
This study aims to analyze the differences between the Rempanga Village Government Financial Statements of TA 2016 and Permendagri Number 113 of 2014, and to know and analyze the process of preparing the Rempanga Village Government Financial Statements for Fiscal Year 2016 through the accounting cycle.

The hypothesis of this study is that there is a difference between the Rempanga Village Government Financial Report 2016 and Permendagri Number 113 of 2014, and the accounting cycle is not carried out in the process of compiling the Rempanga Village Government Financial Report for Fiscal Year 2016.

The basis of this research theory uses Permendagri Number 113 of 2014 concerning Village Financial Management. In this study the author uses a comparative analysis tool that compares the Realization Accountability Report of the Village Budget Implementation for Fiscal Year 2016, Village Property Report as of December 31, Fiscal Year 2016, and Government and Regional Government Program Reports that enter the village in the form of Financial Statements in accordance with Financial Management Guidelines Village Permendagri Number 113 of 2014 and using the method of observation that is observing in documents which are outputs from the implementation of the accounting cycle in the form of journal memos, ledgers, unadjusted balance sheets, adjusting journal entries, and adjusted trial balance.

The results of the study concluded that there were 11 Differences between the Rempanga Village Government Financial Statements of Fiscal Year 2016 with the Village Financial Management Guidelines Permendagri 113 of 2014 which were 4 differences found from observations of the Rempanga Village Government Financial Statements Fiscal Year 2016, and there were 7 differences found from interviews with the Village Secretary Rempanga as Financial Management Technical Implementation Coordinator. These differences have shown that the accounting cycle is not carried out in the process of compiling the Rempanga Government Financial Report Fiscal Year 2016, the hypothesis is accepted.
\end{abstract}

Keywords: Village Government Financial Reports, Village Financial Management Guidelines, Permendagri 113 of 2014

\section{PENDAHULUAN}

Undang-Undang Nomor 6 Tahun

2014 tentang Desa beserta peraturan pelaksanaannya telah mengamanatkan pemerintah desa untuk lebih mandiri dalam mengelola pemerintahan dan berbagai sumber daya alam yang 
dimiliki, termasuk di dalamnya pengelolaan keuangan dan kekayaan milik desa. Begitu besar peran yang diterima oleh desa, tentunya disertai dengan tanggung jawab yang besar pula. Oleh karena itu pemerintah desa harus bisa menerapkan prinsip akuntabilitas dalam tata pemerintahannya, dimana semua akhir kegiatan penyelenggaraan pemerintahan desa harus dapat dipertanggungjawabkan kepada masyarakat desa sesuai dengan ketentuan.

Proses Penyusunan pelaporan desa pada awalnya berpedoman pada Permendagri Nomor 37 Tahun 2007 tentang Pedoman Pengelolaan Keuangan Desa. Setelah UndangUndang Nomor 6 Tahun 2014 tentang Desa terbit, maka Peraturan Menteri Dalam Negeri Nomor 37 Tahun 2007 dicabut dan dinyatakan tidak berlaku lagi dan kemudian diganti dengan Permendagri 113 tahun 2014 tentang Pengelolaan Keuangan Desa pada tanggal 31 Desember 2014.

Kesenjangan yang terjadi antara harapan (teori) dengan kenyataan akibat dilaksanakan peraturan baru ini adalah ketidaksiapan pejabat teknis pengelola keuangan desa (PTPKD) dalam melakukan penyusunan pelaporan keuangan desa sehingga dapat menurunkan kualitas pelaporan keuangan yang merupakan bentuk pertanggungjawaban pengelolaan keuangan pemerintah desa. Selain itu, ketidaksiapan PTPKD juga dapat menurunkan kredibilitas, transparansi, dan akuntabilitas pengelolaan keuangan pemerintah desa.

Permendagri Nomor 113 Tahun 2014 tidak mudah diimpelementasikan dalam proses penyusunan laporan keuangan pemerintah desa karena pemerintah desa dituntut harus mampu menyajikan jumlah pelaporan yang beragam sebagai bentuk pertanggungjawaban penyelenggaraan pemerintahan desa selama satu tahun anggaran kepada masyarakat desa. Apabila dilihat dari SDM pemerintah desa yang kurang memadai, banyak pihak mengkhawatirkan pemerintah desa tidak mampu menyajikan pelaporan keuangan sesuai dengan ketentuan yang berlaku. Pemerintah desa juga belum memiliki prosedur dan dukungan sarana prasarana dalam pengelolaan keuangannya khususnya pelaporan dan pertanggunggjawaban keuangan. Besarnya dana yang diamanatkan kepada pemerintah desa 
harus dikelola dengan baik dan jangan sampai menjadi bencana bagi pemerintah desa. Aparatur Pemerintah Desa dan Badan Permusyawaratan Desa (BPD) harus memiliki pemahaman atas peraturan perundang-undangan dan ketentuan lainnya, serta memiliki kemampuan untuk melaksanakan akuntansi dan pembukuan.

Permendagri 113 tahun 2014 mensyaratkan bahwa Laporan Keuangan Pemerintah Desa yang merupakan Laporan pertanggungjawaban realisasi pelaksanaan APBDesa harus ditetapkan dengan Peraturan Desa dan dilampiri dengan Laporan Pertanggungjawaban Realisasi Pelaksanaan APBDesa Tahun Anggaran berkenaan, Laporan Kekayaan Milik Desa per 31 Desember Tahun Anggaran berkenaan, dan Laporan Program Pemerintah dan Pemerintah Daerah yang masuk ke desa. Oleh karena itu, pemberlakuan Permendagri Nomor 113 Tahun 2014 tersebut akan berbenturan dengan pelaksanaan teknis di lapangan.

Sehubungan dengan Permendagri Nomor 113 Tahun 2014 merupakan pedoman penyusunan laporan keuangan desa yang sudah wajib diterapkan di Lingkungan Pemerintah desa mulai
Tahun Anggaran 2016, penulis akan menganalisis ketidaksesuaian antara laporan keuangan pemerintah desa dengan pedoman Permendagri Nomor 113 Tahun 2014 secara deskriptif kualitatif (Studi Kasus Pada Laporan Keuangan TA 2016 Pemerintah Desa Rempanga).

\section{KERANGKA TEORITIS}

\section{Akuntansi Sektor Publik}

Akuntansi Sektor Publik memiliki perbedaan dengan Akuntansi Sektor Swasta. Hal yang paling mencolok antara Akuntansi Sektor Publik dengan Akuntansi Sektor Swasta adalah pada bagian instansi yang menggunakannya. Akuntansi Sektor Publik biasanya terkait dengan organisasi Pemerintah Pusat, Pemerintah Daerah, dan Pemerintahan Desa.

\section{Pengertian Akuntansi}

Abdul Halim (2012:16) memberikan definisi Akuntansi sebagai berikut :

Akuntansi menurut asal katanya yaitu berasal dari kata Accountancy/Accounting/Consti tuency yang diserap ke dalam bahasa Indonesia, akuntansi yang berarti sebuah aktivitas 


\begin{abstract}
atau proses dalam mengidentifikasi, mencatat, mengklasifikasi, mengolah dan menyajikan data yang berhubungan dengan keuangan atau transaksi agar mudah dimengerti dalam mengambil keputusan yang tepat. Banyak pendapat yang mendefinisikan pengertian akuntansi ini, baik yang menjelaskan berbeda maupun tak sedikit yang menjelaskan hampir sama.
\end{abstract}

\section{Akuntansi Pemerintahan}

Berdasarkan pengertian pemerintah daerah, maka Akuntansi Pemerintah Daerah menurut Bachtiar Arif (2010:3) adalah : "Aktivitas pemberian jasa untuk menyediakan suatu informasi keuangan pemerintah berdasarkan proses pencatatan, pengklasifikasian, penafsiran atas informasi keuangan serta pengikhtisaran suatu transaksi keuangan pemerintah tersebut". Standar Akuntansi yang dianut dalam pelaporan keuangan tersebut harus ditetapkan dalam bentuk peraturan perundangan-undangan yang berlaku bagi instansi-instansi atau organisasi-organisasi pemerintahan yang bersangkutan.

\section{Standar Akuntansi Pemerintahan (SAP)}

Undang-Undang Nomor 17 Tahun 2003 tentang Keuangan Negara dalam pasal 32 mengamanatkan bahwa: "bentuk dan isi laporan pertanggungjawaban pelaksanaan APBN/APBD disusun dan disajikan sesuai dengan Standar Akuntansi Pemerintahan". Standar akuntansi pemerintahan tersebut disusun oleh Komite Standar Akuntansi Pemerintahan yang independen dan ditetapkan dengan Peraturan Pemerintah setelah terlebih dahulu mendapat pertimbangan dari Badan Pemeriksa Keuangan.

Peraturan Pemerintah Nomor 71 Tahun 2010 memberikan definisi Standar Akuntansi Pemerintahan yaitu : "prinsip-prinsip akuntansi yang diterapkan dalam menyusun dan menyajikan laporan keuangan pemerintah". Dengan demikian SAP merupakan persyaratan yang mempunyai kekuatan hukum dalam upaya meningkatkan kualitas laporan keuangan di Indonesia.

\section{Siklus Akuntansi}

Siklus akuntansi adalah proses pencatatan transaksi dimulai dari 
analisis dokumen sumber sampai dengan penyusunan laporan keuangan, dilanjutkan dengan jurnal penutupan dan Neraca Saldo Setelah Penutupan. Pemahaman mengenai Siklus Akuntansi sangat penting untuk mengetahui proses penyusunan laporan keuangan. Pemahaman tersebut juga akan memudahkan untuk menganalisis transaksi secara parsial dan dampaknya pada laporan keuangan.

\section{Badan Pengawasan Keuangan} dan Pembangunan (2012:18-38) menjabarkan tahapan-tahapan siklus akuntansi sebagai berikut :

1. Identifikasi transaksi;

2. Memindahbukukan (posting) transaksi akuntansi dari jurnal ke buku besar;

3. Menyusun neraca saldo;

4. Membuat jurnal penyesuaian dan membukukan (posting) jurnal penyesuaian ke buku besar;

5. Menyusun neraca saldo setelah penyesuaian.

6. Menyusun laporan keuangan berdasarkan neraca saldo setelah penyesuaian;

7. Membuat jurnal penutup dan membukukan (posting) jurnal penutup ke buku besar;
8. Menyusun neraca saldo setelah penutupan;

9. Membuat jurnal pembalik dan membukukan (posting) jurnal pembalik ke buku besar.

\section{Pengertian Laporan Keuangan}

Laporan keuangan merupakan laporan tertulis yang memberikan informasi kuantitatif tentang posisi keuangan dan perubahan-perubahannya, serta hasil yang dicapai selama periode tertentu. Laporan keuangan dapat dijadikan media yang dapat dipakai untuk meneliti kondisi kesehatan suatu entitas pelaporan, yang mana laporan keuangan tersebut terdiri dari neraca, perhitungan rugi laba, ikhtisar laba ditahan, dan laporan posisi keuangan. Ikatan Akuntan Indonesia (2009:3) mengartikan laporan keuangan adalah : "susunan yang menyajikan posisi keuangan dan kinerja keuangan dalam sebuah entitas".

\section{Laporan Pertanggungjawaban}

Realisasi Pelaksanaan APB Desa

Permendagri 113 tahun 2014 mengamanatkan bahwa Laporan Pertanggungjawaban Realisasi Pelaksanaan APB Desa merupakan laporan yang disampaikan secara 
periodik kepada BPD terhadap pelaksanaan APB Desa yang telah disepakati di awal tahun dalam bentuk Peraturan Desa. Laporan Pertanggungjawaban Realisasi Pelaksanaan APB Desa dilampiri :

1. Laporan Pertanggungjawaban Realisasi Pelaksanaan APB Desa Tahun Anggaran berkenaan;

2. Laporan Kekayaan Milik Desa per 31 Desember Tahun Anggaran berkenaan; dan

3. Laporan Program Pemerintah dan Pemerintah Daerah yang Masuk ke Desa.

\section{METODOLOGI PENELITIAN}

Penelitian ini dilakukan pada Pemerintah Desa Rempanga, Kecamatan Loa Kulu, Kabupaten Kutai Kartanegara. Penelitian ini dilakukan dengan menggunakan penelitian deskriptif kualitatif karena penelitian ini bersifat menganalisis Laporan Keuangan Pemerintah Desa Rempanga TA 2016 dengan cara membandingkan mekanisme penyusunan dan penyajian Laporan Keuangan Pemerintah Desa Rempanga TA 2016 dengan :

1. Pedoman Pengelolaan Keuangan Desa Permendagri Nomor 113 Tahun 2014; dan
2. Siklus akuntansi.

Penelitian ini juga mengalisis apakah terdapat pembinaan dalam penyusunan Laporan Keuangan oleh pemangku kepentingan keuangan.

ANALISIS DAN PEMBAHASAN

Analisis Kesesuaian Laporan

Keuangan Pemerintah Desa

Rempanga TA 2016 dengan Pedoman Pengelolaan Keungan Desa Permendagri 113 Tahun 2014

Pemerintah Desa Rempanga telah membuat pertanggungjawaban penggunaan dan pengelolaan sumber daya yang dimilikinya. Bentuk pertanggungjawaban tersebut dituangkan dalam Peraturan Desa Rempanga Nomor 1 Tahun 2017 tentang Laporan Pertanggungjawaban Realisasi Pelaksanaan Anggaran Pendapatan Dan Belanja Desa Tahun Anggaran 2016, yang merupakan kesepakatan bersama antara Badan Permusyawaratan Desa Rempanga dengan Kepala Desa Rempanga.

Pertanggungjawaban realisasi pelaksanaan APBDes TA 2016 tersebut berupa laporan keuangan yang memuat Laporan Realisasi Pelaksanaan APBDes 
TA 2016, Neraca Per 31 Desember Tahun 2016, dan Laporan Program Pemerintah dan Pemerintah Daerah yang Masuk ke Desa. Bentuk Laporan Keuangan Pemerintah Desa Rempanga TA 2016 adalah sebagai berikut:

1. Kode rekening belanja pada Laporan Pertanggungjawaban Realisasi Pelaksanaan APBDes TA 2016 belum mengacu pada kode rekening Permendagri 113 Tahun 2014. Kode rekening belanja pada Laporan Pertanggungjawaban Realisasi Pelaksanaan APBDes TA 2016 disajikan sampai level 5, sedangkan kode rekening pada Permendagri 113 Tahun 2014 hanya sampai level 4;

2. Terdapat belanja operasional PKK, Karang Taruna, Kegiatan LPM, dan Kepanitiaan LPTQ yang tidak dirinci jenis belanjanya sehingga tidak dapat diketahui klasifikasi realisasi belanjanya termasuk dalam jenis belanja pegawai atau belanja barang dan jasa atau belanja modal;

3. Pemerintah Desa Rempanga TA 2016 telah mencatat Aset Lancar, Aset Tetap, dan Utang pada Laporan Keuangan TA 2016 yaitu dalam Neraca Per 31 Desember Tahun 2016. Pemerintah Desa Rempanga menggunakan nomenklatur neraca per 31 Desember dalam Laporan Keuangan TA 2016, sedangkan Permendagri 113 Tahun 2014 menggunakan nomenklatur Laporan Kekayaan Milik Desa Sampai Dengan 31 Desember untuk mencatatkan Aset, Kewajiban Jangka Pendek, dan Kekayaan Bersih;

4. Neraca Per 31 Desember 2016 dalam Laporan Keuangan TA 2016 hanya menyajikan Aset dan Kewajiban, sementara Jumlah Kekayaan Bersih yang merupakan selisih antara Jumlah aset dengan Jumlah Kewajiban Jangka Pendek tidak disajikan;

5. Pemerintah Desa Rempanga telah menyajikan Aset Tetap dalam Laporan Kekayaan Milik Desa Sampai Dengan 31 Desember 2016. Terdapat salah saji atas Aset Tetap dalam Laporan Kekayaan Milik Desa Sampai Dengan 31 Desember 2016 yaitu jenis Aset Tetap gedung dan bangunan disajikan secara gabungan dengan jenis Aset Tetap Jalan, Jaringan, dan Instalasi yaitu sebesar Rp.655.209.059,-;

6. Laporan Program Pemerintah dan Pemerintah Daerah Yang Masuk Ke Desa Tahun Anggaran 2016 belum 
sepenuhnya menyajikan kegiatankegiatan baik yang dilakukan oleh Pemerintah Pusat maupun Pemerintah Kabupaten Kutai Kartanegara yang dilaksanakan di Desa Rempanga;

7. Terdapat Pendapatan yang berasal dari pendapatan jasa giro bank dan pengeluaran berupa biaya administrasi bank yang tidak dicatat dalam Laporan Realisasi Pelaksanaan APBDes TA 2016;

8. Terdapat kesalahan penganggaran dalam Peraturan Desa tentang APBDes $\quad$ TA 2016 yaitu pengeluaran yang seharusnya dianggarkan dalam belanja modal tetapi justru dianggarkan dalam belanja barang dan jasa, dan juga sebaliknya;

9. Pengeluaran dalam rangka pembayaran upah pekerja pembangunan konstruksi desa dianggarkan dalam belanja barang dan jasa serta belum diatribusikan/digabungkan dalam nilai perolehan aset tetap;

10. Stock opname atau Inventarisasi atas persediaan yang masih tersisa per 31 Desember 2016 tidak dilakukan sehingga nilai persediaan tidak disajikan dalam LKMD Rempanga sampai dengan 31 Desember 2016;

11. Inventarisasi atas aset desa belum dilakukan secara menyeluruh sehingga aset desa yang dicatat dalam Laporan Kekayaan Milik Desa Rempanga sampai dengan 31 Desember 2016 merupakan aset desa yang berasal dari realisasi belanja modal tahun 2014 sampai dengan 2016.

Analisis Kesesuaian Laporan Keuangan Pemerintah Desa Rempanga TA 2016 dengan Pedoman Pengelolaan Keungan Desa

\section{Permendagri 113 Tahun 2014}

Laporan Realisasi Pelaksanaan APBDes TA 2016 dan Laporan Kekayaan Milik Desa Sampai Dengan 31 Desember 2016 disusun dengan menggunakan data-data transaksi keuangan yang telah dicatat sebelumnya dalam Buku Kas Umum (BKU) bendahara, Buku Pembantu Tunai, Buku Pembantu Bank, dan Buku Pembantu Pajak tanpa melalui siklus akuntansi yang benar.

Proses penyusunan Laporan Realisasi Pelaksanaan APBDes TA 2016 dan Laporan Kekayaan Milik Desa Sampai Dengan 31 Desember 
2016 tersebut hanya dilakukan melalui analisis terhadap transaksi-transaksi yang terjadi selama satu periode dan selanjutnya dilakukan penyusunan Laporan Realisasi Pelaksanaan APBDes TA 2016 dan Laporan Kekayaan Milik Desa Sampai Dengan 31 Desember 2016 dari hasil analisis transaksitransaksi tersebut tanpa membuat memo jurnal, pemindahbukuan (posting) ke dalam buku besar, Neraca Saldo, dan Jurnal Penyesuaian.

Hal tersebut menyebabkan informasi-informasi yang terdapat dalam Laporan Realisasi Pelaksanaan APBDes TA 2016 dan Laporan Kekayaan Milik Desa Sampai Dengan 31 Desember 2016 belum sepenuhnya valid dan dapat dipertanggungjawabkan.

\section{Pembahasan}

Kewajiban untuk melaporkan Pertanggungjawaban Realisasi Pelaksanaan APBDesa kepada Bupati Kutai Kartanegara setiap akhir tahun anggaran tersebut, tentunya menuntut Sumber Daya Manusia (SDM) Pemerintah Desa Rempanga untuk memahami akuntansi dan pelaporan keuangan. Kurangnya pemahaman terhadap akuntansi dan pelaporan keuangan tentunya merupakan salah satu hal yang menyebabkan 11 (sebelas) perbedaan antara Laporan Keuangan Pemerintah Desa Rempanga TA 2016 dengan Pedoman Pengelolaan Keuangan Desa Permendagri 113 tahun 2013 dan tidak dilakukannya siklus akuntansi.

Hal tersebut diatas menuntut Pemerintah Desa Rempanga untuk melakukan pembinaan terhadap Sumber Daya Manusia (SDM) yang berkaitan dengan pengelolaan keuangan desa dalam peningkatan pemahaman akuntansi dan pelaporan keuangan. Sumber Daya Manusia (SDM) Pemerintah Desa Rempanga pada tahun 2016 yang mempunyai latar belakang pendidikan akuntansi hanya berjumlah 9 (sembilan) personil yaitu 8 (delapan) personil berlatar pendidikan SMK Akuntansi dan 1 (satu) personil berlatar pendidikan Strata 1 (S1) Akuntansi. Pembinaan Sumber Daya Manusia (SDM) dapat dilakukan dengan menambah atau merekrut personil baru yang mempunyai latar belakang pendidikan akuntansi, dan/atau dengan mengikutsertakan personil yang sudah ada untuk mengikuti pendidikan dan pelatihan yang berkaitan dengan akuntansi dan pelaporan keuangan. 
Selain itu sarana prasarana pendukung dalam pencatatan dan pembukuan transaksi-transaksi keuangan juga harus disiapkan seperti implementasi Aplikasi SISKEUDES yang telah disediakan oleh Pemerintah Pusat yang dalam hal ini Kementerian Dalam Negeri yang bekerja sama dengan Badan Pengawasan Keuangan dan Pembangunan (BPKP). Aplikasi SISKEUDES sebenarnya telah dilakukan sosialisasi dan diujicobakan pada Pemerintah Desa Rempanga tetapi baru dilakukan pada Bulan Desember 2016 sehingga belum dapat digunakan untuk melakukan pencatatan seluruh transaksi keuangan Pemerintah Desa Rempanga dari Januari sampai dengan Desember tahun 2016.

$$
\text { Implementasi Aplikasi }
$$

SISKEUDES secara menyeluruh pada proses pengelolaan keuangan desa yaitu mulai dari proses perencanaan, penganggaran, penatausahaan, sampai dengan proses pelaporan dan pertanggungjawaban keuangan tentunya akan sangat membantu Pemerintah Desa Rempanga dalam pengelolaan keuangan desa. Aplikasi SISKEUDES mampu menghasilkan laporan-laporan yang dipersyaratkan Permendagri 113 tahun 2016 dan pembukuan hasil dari pelaksanaan siklus akuntansi seperti Memo Jurnal, Buku Besar, Neraca Saldo, Memo Jurnal Penyesuaian, dan Laporan Keuangan.

\section{KESIMPULAN DAN SARAN}

\section{Kesimpulan}

Berdasarkan analisis dan penelitian maka dapat ditarik kesimpulan sebagai berikut:

1. Penyajian Laporan Keuangan Pemerintah Desa Rempanga TA 2016 belum sepenuhnya sesuai dengan Pedoman Pengelolaan Keuangan Desa Permendagri 113 Tahun 2014 yang disebabkan karena belum adanya mekanisme SOP penyusunan Laporan Keuangan Pemerintah Desa Rempanga yang memastikan Laporan Keuangan Pemerintah Desa telah sesuai dengan Permendagri 113 Tahun 2016, dan lemahnya SDM Pemerintah Desa Rempanga di bidang akuntansi dan pelaporan keuangan sehingga menyebabkan salah saji dalam pelaporan keuangan.

2. Proses penyusunan Laporan Keuangan Pemerintah Desa Rempanga TA 2016 belum dilakukan melalui siklus akuntansi 
karena belum menggunakan Aplikasi

Pengelolaan Keuangan Desa.

\section{Saran}

Berdasarkan kesimpulan maka saran-saran yang dapat diberikan sebagai berikut:

1. Pemerintah Desa Rempanga agar membuat SOP penyusunan Laporan Keuangan Pemerintah Desa Rempanga yang memastikan Laporan Keuangan Pemerintah Desa telah sesuai dengan Permendagri 113 Tahun 2016 dan siklus akuntansi telah dilakukan.

2. Pemerintah Desa Rempanga agar menyiapkan SDM yang kompeten dalam bidang akuntansi dan pelaporan keuangan serta menguasai Aplikasi Pengelolaan Keuangan Desa.

3. Pemerintah Desa Rempanga agar melakukan implementasi Aplikasi SISKEUDES secara menyeluruh pada proses pengelolaan keuangan desa yaitu mulai dari proses perencanaan, penganggaran, penatausahaan, sampai dengan proses pelaporan keuangan.

Diharapkan Laporan Keuangan Pemerintah Desa Rempanga dapat disajikan sesuai dengan yang dipersyaratkan pada Pedoman Pengelolaan Keuangan Desa Permendagri 113 Tahun 2014 dan disusun melalui siklus akuntansi, sehingga informasi-informasi yang terdapat dalam Laporan Keuangan Pemerintah Desa Rempanga dapat digunakan oleh stakeholder dalam pelaksanaan pembangunan di Desa Rempanga.

\section{DAFTAR PUSTAKA}

2012. Modul Pelatihan DasarDasar Akuntansi. Jakarta.

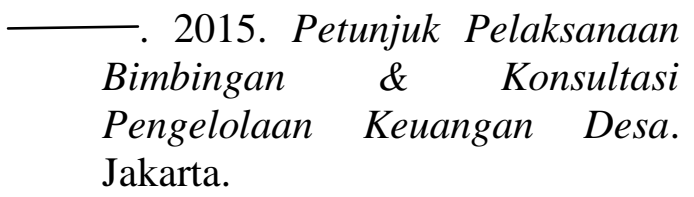

- 2016. Pengelolaan Keuangan Desa. Jakarta.
-. 2008. Akuntansi Keuangan Dasar. BPFE: Yogyakarta.

2009. Akuntansi Sektor Publik. Andi: Jakarta.

-2010. Standar Akuntansi Pemerintah Berbasis Akrual : PP Nomor 71 Tahun 2010. KSAP.

- 2014. Peraturan Menteri Dalam Negeri Nomor 113 Tahun 2014 tentang Pengelolaan keuangan Desa (Berita Negara Republik Indonesia Tahun 2014 Nomor 2093). Menteri Dalam Negeri Republik Indonesia. 
- 2017. Peraturan Desa Rempanga Nomor 1 Tahun 2017 tentang Laporan Pertanggungjawaban Realisasi Pelaksanaan Anggaran Pendapatan dan Belanja Desa Tahun Anggaran 2016 (Lembaran Desa Rempanga Tahun 2017 Nomor 1). Sekretaris Desa Rempanga.

Anggalarang, Sulaiman. 2017. Skripsi Evaluasi Efektivitas Pengelolaan Dana Desa Studi Kasus Pada Desa Panggungharjo, Sewon Bantul Daerah Istimewa Yogyakarta. Purwokerto: Fakultas Ekonomi dan Bisnis Universtas Jenderal Soedirman.
Arif, Bachtiar dkk. 2010. Akuntansi Pemerintahan. Salemba Empat: Jakarta

Halim, Abdul. 2012. Akuntansi Keuangan Daerah, Edisi Keempat. Selemba Empat: Jakarta.

Indra Bastian. 2007. Sistem Akuntansi Sektor Publik, Edisi Kedua. Salemba Empat: Jakarta.

Ismail, Muhammad, Ari Kuncara Widagdo, dkk. 2016. Sistem Akuntansi Pengelolaan Dana Desa. Jurnal Ekonomi dan Bisnis, Vol. XIX No.2, Agustus 2016, ISSN 1979-6471. 